\title{
DIGITAL TRANSFORMATION MODEL FOCUSED ON PERUVIAN INDUSTRIAL FISHING
}

Pedro Martín Lezama Gonzales

National University Federico Villarreal, Lima, (Perú).

E-mail:plezama@unfv.edu.pe

ORCID: https://orcid.org/0000-0001-9693-0138

Giro Rodriguez Rodriguez

National University Federico Villarreal, Lima, (Perú).

E-mail: crodriguez@unfv.edu.pe

ORCID: https://orcid.org/0000-0003-2112-1349

Francisco Manuel Hilario Falcón

National University Federico Villarreal, Lima, (Perú).

E-mail: fhilario@unfv.edu.pe

ORCID: https://orcid.org/0000-0003-3153-9343

Jorge Víctor Mayhuasca Guerra

National University Federico Villarreal, Lima, (Perú).

E-mail: jmayhuasca@unfv.edu.pe

ORCID: https://orcid.org/0000-0002-6465-4738

\section{Gitación sugerida:}

Lezama, P. M., Rodriguez, G. R., Hilario, F. M., y Mayhuasca, J. V. (2022). Digital transformation model focused on Peruvian industrial fishing. 3C Tecnología. Glosas de innovación aplicadas a la pyme, Edición Especial, (febrero 2022), 237-255. https://doi.org/10.17993/3ctecno.2022.specialissue9.237-255 


\section{ABSTRACT}

The objectives of this research work were to determine the degree of improvement in the efficiency of the digital transformation, the efficiency in the extraction of fishing and the performance and the reference in the implementation of the digital transformation in the processes of extraction of fishing. A proposal for a model of digital transformation of processes was shown that helps in the improvement of the fishing production management process based on time, resources, profits and the collection of information on the entry and exit of the fisheries. Now they must be responsible for taking conditions at the time of carrying out the strategic method that will improve the production processes and be able to control the objectives based on bar charts. The development of technological change will allow monitoring alerts and obtaining control through devices within the reach of any responsible user. In summary, the results were the product of the comparative analysis of the last 4 years of fishing, due to the changes between fishing seasons

\section{KEYWORDS}

M-Learning, Digital Transformation Model, Operational Efficiency, Efficiency and yield of crops and references. 


\section{INTRODUCTION}

\subsection{DESCRIPTION OF PROBLEM}

The FAO in its latest report stresses that "society is faced with the enormous task of providing food and livelihoods for a population that will exceed 9 billion people by the middle of the 21 st century, while at the same time solving the problem of the disproportionate effects of climate change and deterioration in the state of the environment as a resource base" (FAO, 2018).

Fish is the largest segment of the food market. "fish consumption accounts for $16 \%$ of the total amount of animal protein consumed in the world.", (FAO, 2018). This assessment of the global fish market is provided by Jürgen Vogele, director of the World Bank's Agriculture and Ecological Services Department.

Industrial fishing despite COVID 19, contributed 1.5\% of GDP in 2020, Fishing industries manage their processes using SAP as the main ERP, however, the extraction process is controlled through customized developments (web and mobile applications), having a delay in data integration, and therefore in decision making.

These industries also do not have an end-to-end management of the extraction process, they only focus on complying with the quotas granted by PRODUCE (Peruvian fishing regulator), sometimes causing overfishing and threatening fish stocks, especially anchoveta.

\subsection{ADAPTING TO TECHNOLOGICAL CHANGE}

Emerging technologies, leveraging the ubiquity of cell phones and tablets, cloud computing, blockchain, have the potential to contribute to data collection. Automating and empowering data processing and analysis, employing business intelligence and analytics tools facilitate the communication of results to relevant stakeholders (Mnatsakanyan \& Kharin, 2021).

Technology can also be used to expand the distribution and accessibility of data to decision makers, enabling them to optimize fishing based on the best available information and transforming unidirectional flows of information (fleet to manager) into a collaborative and mutually beneficial cycle of data collection, synthesis and sharing. 
Adapting organizations from siloed organizational approaches to process-oriented, indicator-based management, agile and value-oriented approaches are objectives that have not yet been fully implemented in fishing companies.

The digital transformation allows a gradual change in fishing companies, allowing an effective use of new technologies and their progressive adaptation in the organization.

\subsection{OBJECTIVES}

- Determine the degree of improvement in operational efficiency (vessel use, fuel use, cycle time) by implementing digital transformation in harvesting processes.

- Determine the degree of improvement in harvesting efficiency (quota advancement, fish quality, quota compliance per fishing trip and per season) by implementing digital transformation in harvesting processes

- Determine the degree of improvement in performance and benchmark (top 6 industrial fishing companies) by implementing digital transformation in harvesting processes.

\section{MATERIALS AND METHODS}

In the research "Opportunities to improve fisheries management through innovative technology and advanced data systems" provides an overview of the current status and challenges of technologically advanced data systems in the fisheries extraction process, and proposes a solution to guide greater use of technology, with the aim of improving fisheries performance (Bradley et al., 2019). 


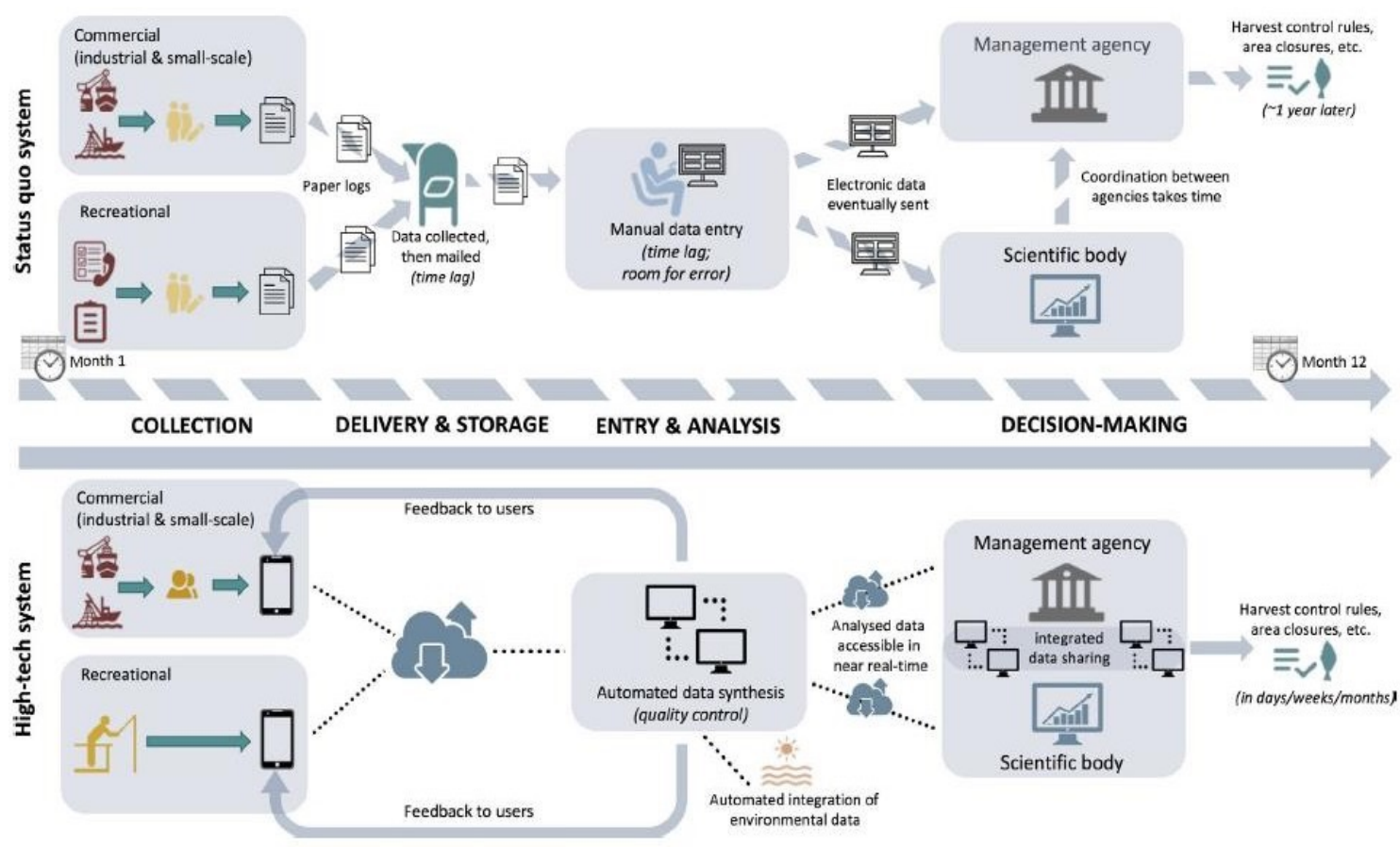

Figure 1. Conceptual diagram of fishery-dependent data collection systems using traditional systems (top) and the use of high technology (bottom).

Source: own elaboration.

\subsection{PROPOSAL DEVELOPMENT}

Next, we will show the conceptual diagram of the proposed digital transformation model based on the improvement of the management process by indicators.

\section{a. Digital transformation model proposal}




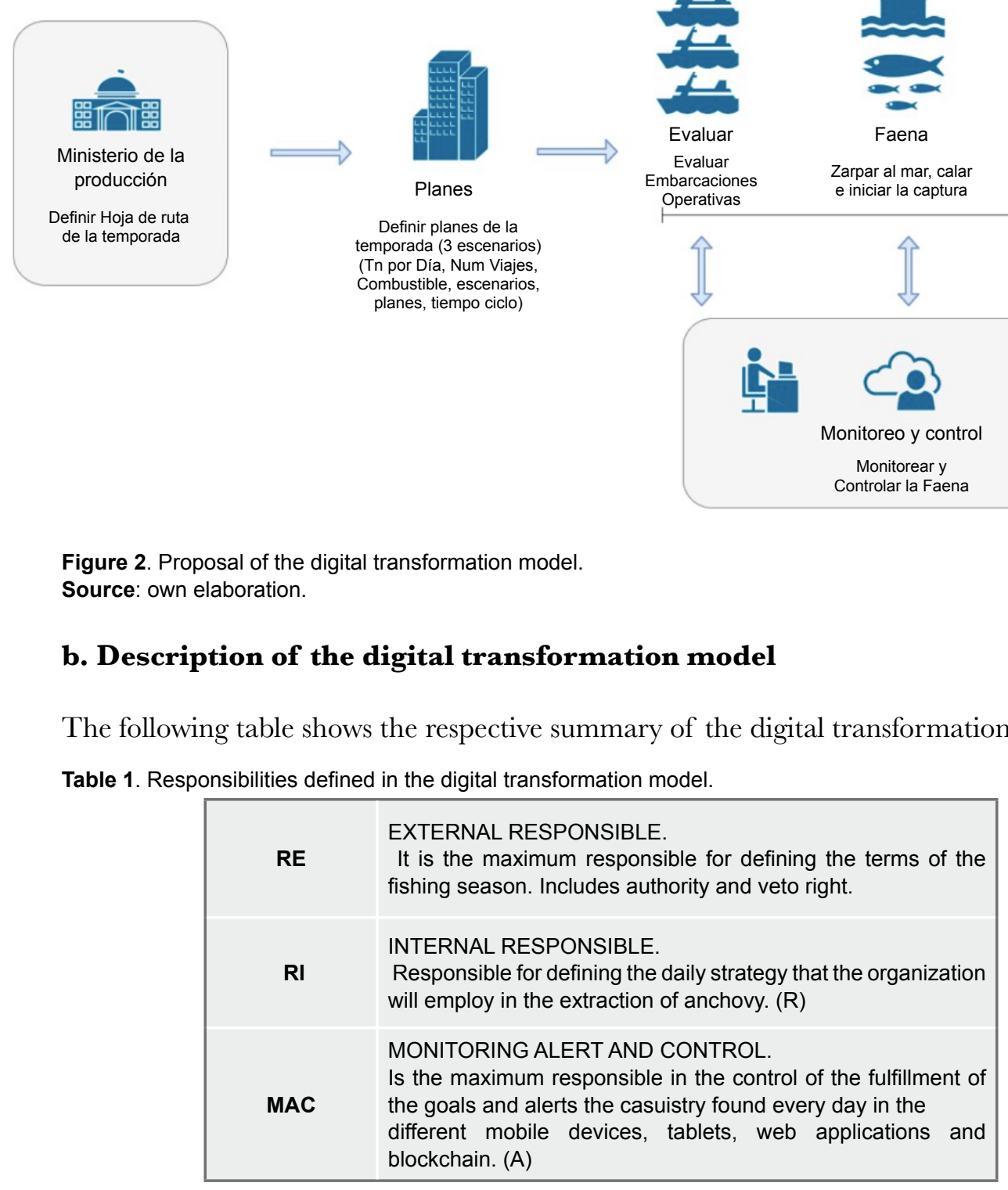

Source: own elaboration.

\section{Asks of the persons in charge}

- $\mathbf{R E}$ is responsible for:

- Evaluating whether the sea state is conducive for fishing. 
- Defining the date on which the two fishing seasons begin.

- Defining the number of days of operation.

- Defining fishing quotas.

- Define the size of the fishery.

- $\quad \mathbf{R I}$ is responsible for:

- Directing the evolutionary strategy of the daily fishing.

- Carrying out fishing plans.

- Carrying out fuel plans.

- Making the fishing chronogram.

- Define the sea route.

- MAG is responsible for:

- Monitoring fuel consumption.

- Monitoring the capacity of the vessel.

- Monitoring the quality of the catch.

- Alerting long unloading times.

- Alerting long waiting times to set sail. o Alerting long waiting times to set sail o Alertinglong waiting times to set sail.

\section{Detail of the tasks}

\section{Assessing the state of the sea}

The Peruvian Ministry of Production carries out an evaluation of the state of the Peruvian sea and defines the areas reserved for artisanal and industrial fishing.

\section{Define season start date}

The Ministry of Production defines the start date of the season after the exploration of the Peruvian sea where it is verified that it is in conditions of exploitation. This procedure is carried out twice a year, in the Peruvian sea there are two extraction seasons. 


\section{Define Quota and magnitude of fishing}

The Ministry of Production defines the fishing magnitude after the evaluation of the Peruvian sea. This magnitude allows the rational exploitation of these hydrobiological resources.

\section{Define days of operation}

The ministry of production defines the days of the season allowing the rational exploitation of these hydrobiological resources.

\section{Define evolutionary strategy}

The organization defines a flexible evolutionary strategy for each fishing day because fishing is volatile. It takes into consideration the three fishing plans, fuel plans, vessel conditions, trip schedules, waiting times for unloading the catch, the time it takes to unload the catch, and the time it takes to wait before setting sail.

\section{Define Fishing Plans}

The organization defines three fishing plans, which allows you to visualize each day the status as the vessels report (favorable plan, intermediate plan, unfavorable plan).

\section{Define Fuel Plans}

The organization defines the fuel plans allowing you to make the plans flexible among the vessels according to their daily consumption and how much they have fished during the season.

\section{Make the trip schedule}

The organization defines the trips that the boats will make according to the weather, sea temperature and the fishing season they are in. To make the schedule more flexible due to navigation setbacks, GPS data is taken from the boats. 


\section{Defining the maritime route}

The organization defines the fishing route in the areas where the Ministry of Production allows it, taking into account historical data and experience of the fleet when defining the route where the anchoveta shoals are found.

\section{Monitoring fuel consumption}

The organization monitors the daily consumption of each vessel and the capacity of the vessel's hold. It analyzes fuel consumption per ton fished and distributes the information on the maritime route taken by the vessel so that the evolutionary fishing strategy can be redefined.

\section{Monitor the vessel's hold capacity.}

The organization monitors the free space of the vessel's hold, if the quantity fished is appropriate the RSW (refrigeration) is used due to the higher fuel consumption, but also ensures the quality of the anchoveta. Likewise, the sensors in the hold calculate the tons caught.

\section{Monitoring the quality of the catch}

The organization monitors the quality in which the anchoveta arrives at the port, dividing it into standard, prime and super prime. When a vessel arrives and fills more than $60 \%$ of its hold, it is decided to use the cold system (RSW) to maintain the highest quality.

\section{Monitoring of fishing zones}

The vessels have sensors, GPS and satellite communication, allowing to know the areas with schools of anchoveta, this allows to alert better fishing areas than those drawn at the beginning of the season in the schedule of trips, to comply with the fishing plan. 


\section{Alerting of waiting time for unloading}

The organization monitors the waiting times for unloading in the ports and can divert the unloading in another port if it is not favorable.

\section{Alerting of unloading times}

The organization monitors vessel unloading times, sensors in the port unloading area send an alert to the vessel when unloading is completed and the actual tons unloaded at the port is declared.

\section{Alerting waiting times for departure}

The organization monitors the time it takes for vessels to depart after anchovies have been unloaded.

\section{Relationships of tasks and responsibilities}

Table 2. Process tasks and their relationship to responsibilities.

\begin{tabular}{|l|c|c|}
\hline PROCESS TASKS & RI & MAC \\
\hline Define fishing plans in three tonnage scenarios & R/A & I \\
\hline Define fuel consumption plans & R/A & I \\
\hline Define the maritime fishing route & R/A & I \\
\hline Make the fishing trip schedule & R/A & R/A \\
\hline Monitor fuel consumption & I & R/A \\
\hline Monitor vessel's hold capacity & I & R/A \\
\hline Monitor the quality of the catch & I & R/A \\
\hline Monitor fishing zones & I & R/A \\
\hline Alerting long unloading times & I & R/A \\
\hline Alerting long waiting times to set sail & I & R/A \\
\hline Alerting long waiting times for unloading & & \\
\hline
\end{tabular}

Source: own elaboration. 


\section{RESULTS}

\section{a) Fishing extraction results for the last 4 years}

The analysis is a comparison of the result of the last 4 years of fishing, due to the changes in the weather between the first and second fishing season, the analysis is divided in two: Season-I and Season-II of the last 4 years.

\section{Progress of tons fished}

\section{Avance de Temporadas - I}

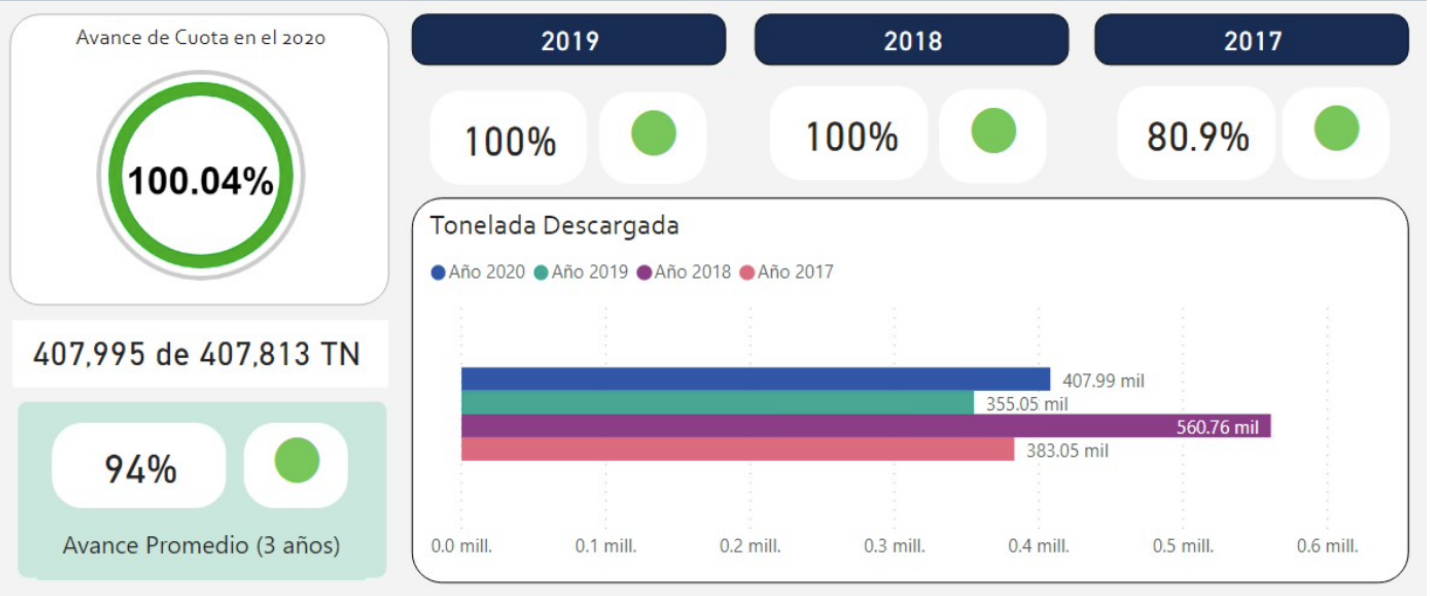

Figure 3. Tons fished advances.

Source: own elaboration.

According to Figure 3, the following was observed:

- In the last 4 years, the goal was reached with the exception of 2017, which only reached $80.9 \%$, narrowly missing the minimum established of $80 \%$. The traffic light for the years 2019, 2018 and 2017 is the comparison with the year 2020 and the average of the 3 years, which is in compliance with what was established.

- In the year 2020 it is observed how the target of 407,813TN (tons) was met and exceeded.

- The bar graph shows the amount of tons fished. Each year is different due to the quota assigned by the Peruvian Ministry of Production. 


\section{Fuel consumption}

\section{Avance de Temporadas - I}

Consumo de combustible en el 2020

\subsection{5 mill.}

Objetivo: 2.453 mill. (+24.79\%)

\section{$2,851 \mathrm{M}$}

Avance Promedio (3 años)

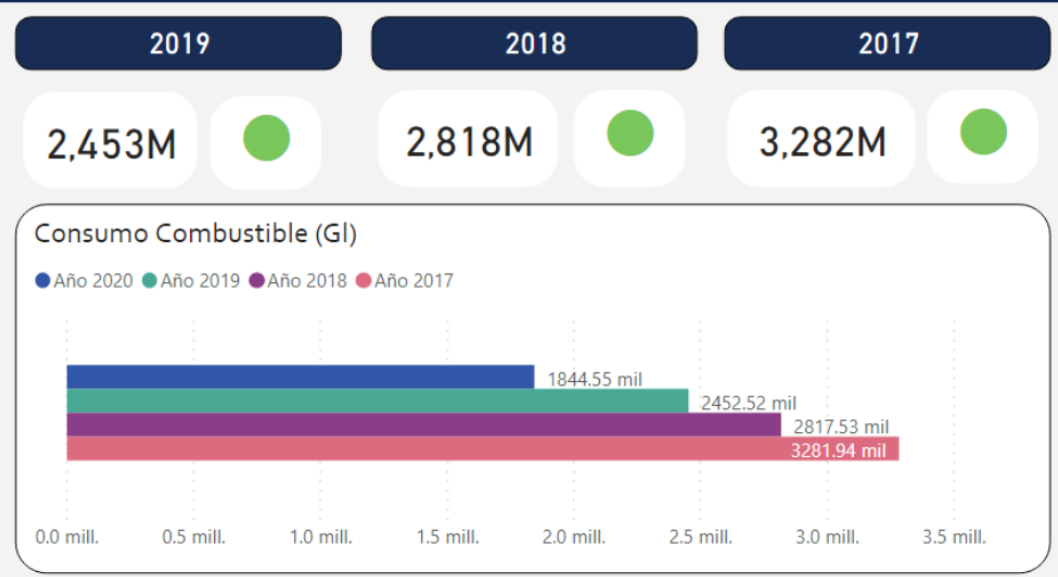

Figure 4. Fuel consumption.

Source: own elaboration.

\section{Fuel consumption GL/TN}

\section{Avance de Temporadas - I}

Consumo de combustible (Galones / tonelada) en el 2020

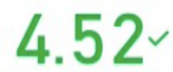

Objetivo: $6.91(+34.55 \%)$

\subsection{3}

Avance Promedio (3 años)

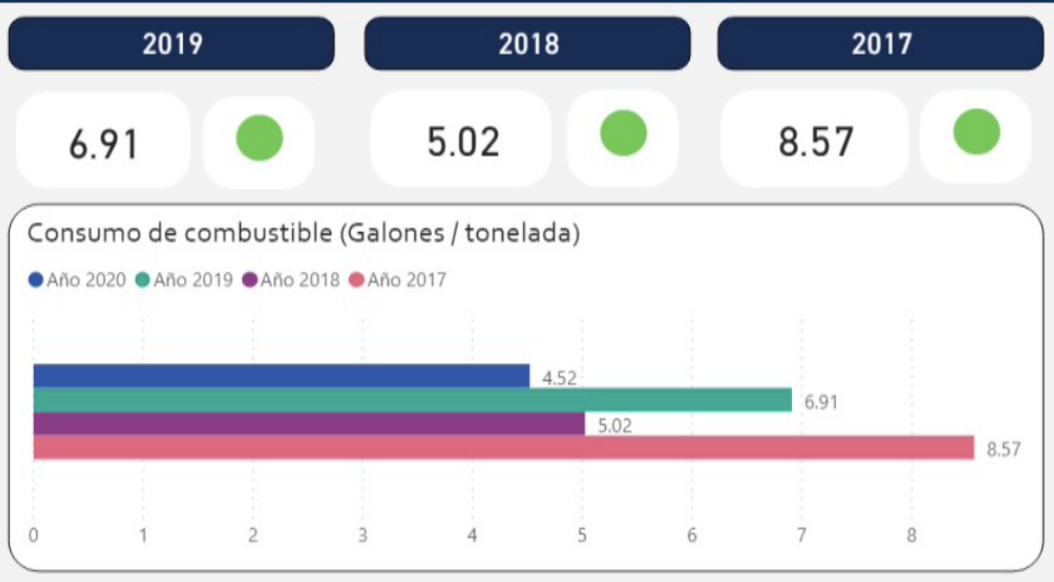

Figure 5. Fuel consumption GL/TN.

Source: own elaboration.

According to Figure 4 and Figure 5, the following was observed:

- Fuel consumption in 2020 is 1.845 million gallons, which is below the consumption of previous years; however, fuel consumption is linked to the quota that the company must fish, which can be seen in the advance graph of tons fished. 


\section{Advancement of vessel performance}

\section{Avance de Temporadas - I}

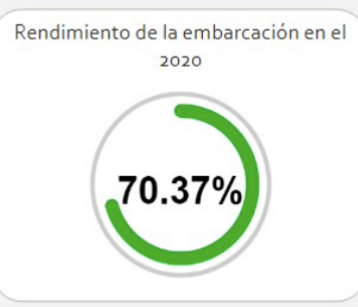

$70.37 \%$ de $54.71 \%$ Proyectado

\section{$50.9 \%$}

Avance Promedio (3 años)

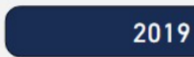

2019 $46.8 \%$

Rendimiento de Captura (\%)

-Año 2020 Año 2019 Año 2018 Año 2017

2018

2017

\section{7}

Figure 6. Advancement of vessel performance.

Source: own elaboration.

According to Figure 6, the following was observed:

- Increasing performance in 2020 compared to previous years.

\section{Analysis by vessel size}

The last 5 years of the fishing season-I are observed.

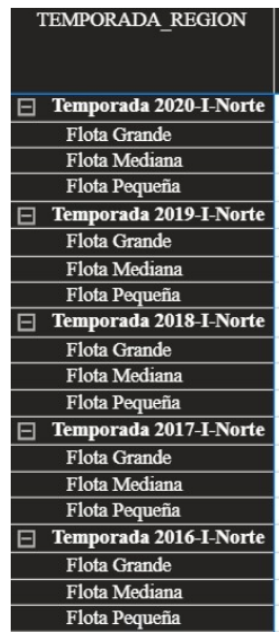

\begin{tabular}{|r|r|}
\hline $\begin{array}{c}\text { Tiempo de } \\
\text { ciclo }\end{array}$ & $\begin{array}{c}\text { Numero de } \\
\text { Viajes }\end{array}$ \\
\hline $\mathbf{3 2 . 5 0}$ & $\mathbf{1 5}$ \\
\hline 39.13 & 217 \\
\hline 31.09 & 104 \\
\hline 32.58 & 27 \\
\hline $\mathbf{3 5 . 3 8}$ & $\mathbf{2 1 6}$ \\
\hline $\mathbf{4 6 . 0 5}$ & 200 \\
\hline 33.97 & 139 \\
\hline 34.90 & 565 \\
\hline $\mathbf{3 3 . 0 0}$ & $\mathbf{2 3 7}$ \\
\hline 37.27 & 296 \\
\hline 32.19 & 1539 \\
\hline 32.94 & 542 \\
\hline $\mathbf{3 6 . 2 8}$ & $\mathbf{2 6 1 8}$ \\
\hline 44.44 & 294 \\
\hline 35.54 & 1695 \\
\hline 34.38 & 629 \\
\hline $\mathbf{9 8 , 5 1 2 . 9 9}$ & $\mathbf{9 9}$ \\
\hline $103,151.25$ & 109 \\
\hline $104,499.28$ & 665 \\
\hline $78,303.65$ & 222 \\
\hline &
\end{tabular}

\begin{tabular}{|r|}
\hline $\begin{array}{c}\text { Capacidad de } \\
\text { Bodega }\end{array}$ \\
\hline $\mathbf{5 7 9 , 7 9 5 . 0 0}$ \\
\hline $122,210.00$ \\
\hline $380,880.00$ \\
\hline $76,705.00$ \\
\hline $\mathbf{7 5 8 , 6 1 5 . 0 0}$ \\
\hline $109,070.00$ \\
\hline $502,950.00$ \\
\hline $146,595.00$ \\
\hline $\mathbf{8 6 7 , 0 7 0 . 0 0}$ \\
\hline $162,710.00$ \\
\hline $561,640.00$ \\
\hline $142,720.00$ \\
\hline $\mathbf{9 3 2 , 3 7 5 . 0 0}$ \\
\hline $158,440.00$ \\
\hline $609,580.00$ \\
\hline $164,355.00$ \\
\hline $\mathbf{3 5 2 , 9 8 5 . 0 0}$ \\
\hline $57,150.00$ \\
\hline $238,080.00$ \\
\hline $57,755.00$ \\
\hline
\end{tabular}

\begin{tabular}{|r|}
\hline $\begin{array}{r}\text { Cantidad consumida } \\
\text { de combustible }\end{array}$ \\
\hline $\mathbf{1 , 8 4 4 , 5 5 4 . 0 0}$ \\
\hline $462,601.00$ \\
\hline $1,107,376.00$ \\
\hline $274,577.00$ \\
\hline $\mathbf{2 , 4 5 2 , 5 2 4 . 0 0}$ \\
\hline $514,884.00$ \\
\hline $1,444,556.00$ \\
\hline $493,084.00$ \\
\hline $\mathbf{2 , 8 1 7 , 5 3 0 . 0 0}$ \\
\hline $644,211.00$ \\
\hline $1,700,942.00$ \\
\hline $472,377.00$ \\
\hline $\mathbf{3 , 2 8 1 , 9 4 2 . 0 0}$ \\
\hline $740,015.00$ \\
\hline $1,963,371.00$ \\
\hline $578,556.00$ \\
\hline $\mathbf{1 , 4 6 7 , 0 7 6 . 0 0}$ \\
\hline $337,194.00$ \\
\hline $883,653.00$ \\
\hline $246,229.00$ \\
\hline
\end{tabular}

\begin{tabular}{|r|r|}
\hline $\begin{array}{c}\text { Toneladas } \\
\text { pescadas }\end{array}$ & $\%$ \\
\hline $\mathbf{4 0 7 , 9 9 4 . 5 0}$ \\
\hline $93,805.22$ \\
\hline $257,138.36$ \\
\hline $57,050.92$ \\
\hline $\mathbf{3 5 5 , 0 4 8 . 5 5}$ \\
\hline $57,522.45$ \\
\hline $228,729.11$ \\
\hline $68,797.00$ \\
\hline $\mathbf{5 6 0 , 7 5 6 . 5 6}$ \\
\hline $116,084.51$ \\
\hline $355,702.15$ \\
\hline $88,969.91$ \\
\hline $\mathbf{3 8 3 , 0 4 7 . 8 2}$ \\
\hline $77,078.04$ \\
\hline $237,197.80$ \\
\hline $68,771.98$ \\
\hline $\mathbf{1 4 2 , 9 9 3 . 3 4}$ \\
\hline $30,632.37$ \\
\hline $89,262.71$ \\
\hline $23,098.27$ \\
\hline
\end{tabular}

\%Avance de la $\%$ Rendimiento temporada

Consumo de combustible

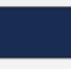


According to Figure 7, the results of the digital transformation are seen in 2020, we visualize a slight reduction in cycle time.

\section{Tons fished for the season - II}

\section{Avance de Temporadas - II}

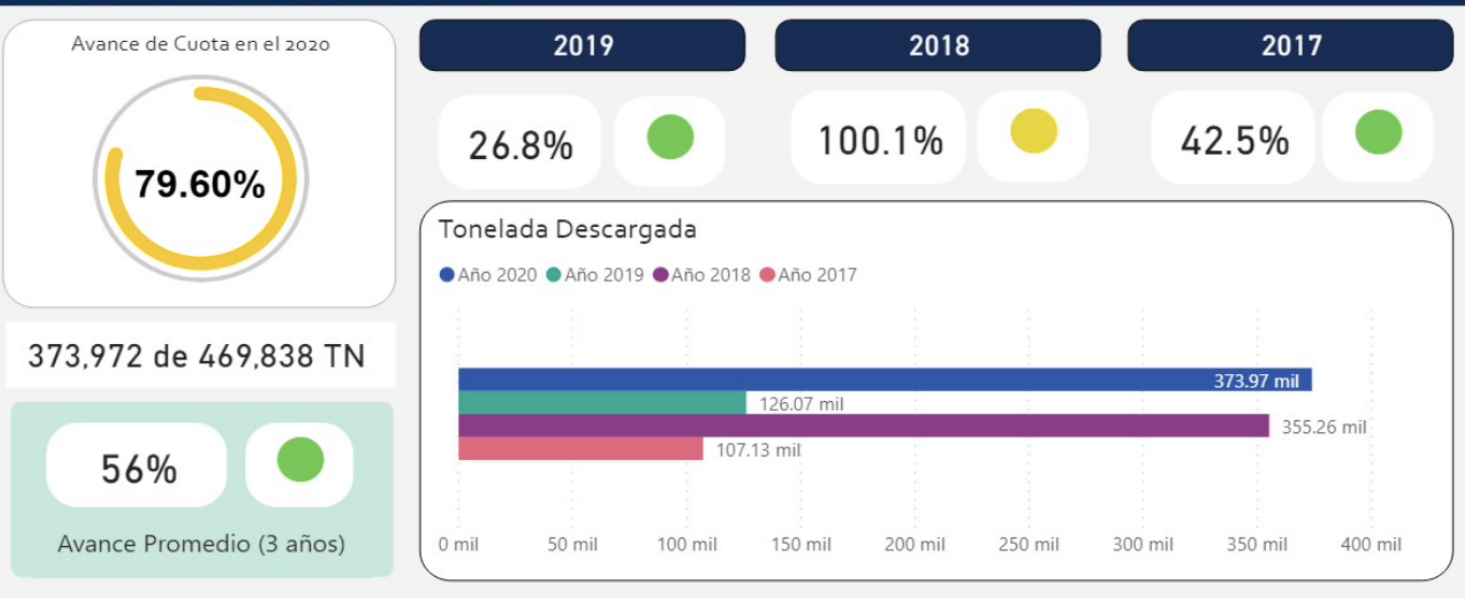

Figure 8. Season progress - II in tons of fish caught, own elaboration.

\section{Advancement of vessel performance}

\section{Avance de Temporadas - II}

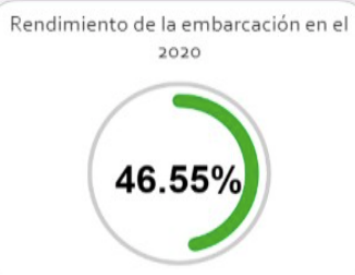

46.55\% de $54.71 \%$ Proyecta..

\section{$41.5 \%$}

Avance Promedio (3 años)
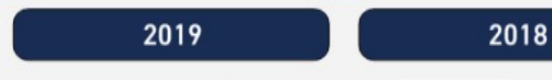

\section{$27.5 \%$}

Rendimiento de Captura (\%)

- Año $2020 \bullet$ Año $2019 \bullet$ Año $2018 \bullet$ Año 2017

$55.2 \%$

$41.8 \%$

Figure 9. Vessel performance reportown elaboration. 


\section{Fuel consumption}

\section{Avance de Temporadas - II}

Consumo de combustible en el 2020

\subsection{5 mill.}

Objetivo: 2.080 mill. (-54.58 \%)

\section{$1,693 \mathrm{M}$}

Avance Promedio (3 años)

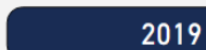

$2,080 \mathrm{M}$

Consumo de combustible (GI)

-Año 2020 Año 2019 Año 2018 Año 2017

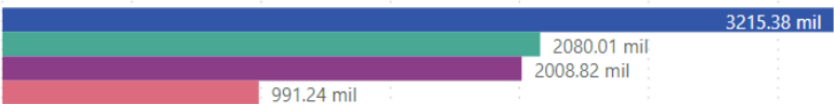

0.0 mill
2018

$2,009 \mathrm{M}$
2017

$991,24 \ldots$

Figure 10. Fuel consumption report.

Source: own elaboration.

\section{Fuel consumption GL/TN}

\section{Avance de Temporadas - II}

Consumo de combustible

(Galones / tonelada) en el 2020

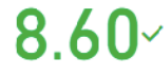

Objetivo: $16.50(+47.89 \%)$

\subsection{7}

Avance Promedio (3 años)

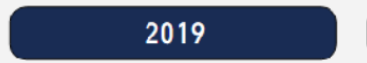

16.50

Consumo de combustible (Galones / tonelada)

- Año 2020 Año $2019 \bullet$ Año 2018 Ar̃o 2017

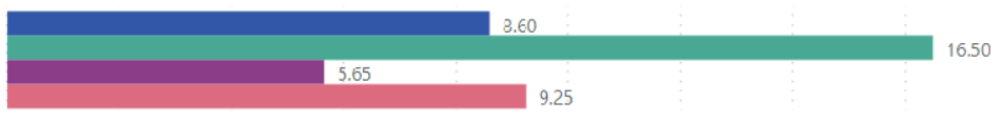

2017

\subsection{5}

Figure 11. GL/TN Fuel Consumption Report.

Source: own elaboration. 


\section{Analysis by vessel size}

The last 5 years of the fishing season-II are observed.

\begin{tabular}{|c|c|c|c|c|c|c|c|c|c|}
\hline TEMPORADA_REGION & $\begin{array}{l}\text { Tiempo de } \\
\text { ciclo }\end{array}$ & $\begin{array}{l}\text { Numero de } \\
\text { Viajes }\end{array}$ & $\begin{array}{c}\text { Capacidad de } \\
\text { Bodega }\end{array}$ & $\begin{array}{l}\text { Cantidad consumida } \\
\text { de combustible }\end{array}$ & $\begin{array}{l}\text { Toneladas } \\
\text { pescadas }\end{array}$ & $\begin{array}{c}\text { \%Avance de la } \\
\text { temporada }\end{array}$ & \%Rendimiento & $\begin{array}{l}\text { Consumo de } \\
\text { combustible } \\
(\mathrm{GL} / \mathrm{H})\end{array}$ & $\begin{array}{l}\text { Consumo de } \\
\text { combustible } \\
\text { (GL/TN) }\end{array}$ \\
\hline 日 Temporada 2020-II-Norte & 35.19 & 2238 & $803,425.00$ & $3,215,377.00$ & $373,972.27$ & $79.60 \%$ & $46.55 \%$ & 49.07 & 8.60 \\
\hline Flota Grande & 43.83 & 246 & $133,220.00$ & $706,462.00$ & $70,495.03$ & $71.45 \%$ & $52.92 \%$ & 76.70 & 10.02 \\
\hline Flota Mediana & 33.81 & 1469 & $531,820.00$ & $1,938,664.00$ & $230,045.37$ & $81.00 \%$ & $43.26 \%$ & 47.31 & 8.43 \\
\hline Flota Pequeña & 34.95 & 523 & $138,385.00$ & $570,251.00$ & $73,431.89$ & $84.24 \%$ & $53.06 \%$ & 37.18 & 7.77 \\
\hline 日 Temporada 2019-II-Norte & 39.81 & 1285 & $458,885.00$ & $2,080,014.00$ & $126,067.44$ & $26.77 \%$ & $27.47 \%$ & 47.58 & 16.50 \\
\hline Flota Grande & 49.19 & 139 & $74,520.00$ & $417,532.00$ & $24,916.26$ & $25.20 \%$ & $33.44 \%$ & 75.80 & 16.76 \\
\hline Flota Mediana & 37.60 & 861 & $310,080.00$ & $1,285,104.00$ & $80,946.45$ & $28.44 \%$ & $26.11 \%$ & 46.66 & 15.88 \\
\hline Flota Pequeña & 41.86 & 285 & $74,285.00$ & $377,378.00$ & $20,204.73$ & $23.13 \%$ & $27.20 \%$ & 35.38 & 18.68 \\
\hline 日 Temporada 2018-II-Norte & 34.23 & 1812 & $643,690.00$ & $2,008,818.00$ & $355,260.56$ & $99.95 \%$ & $55.19 \%$ & 44.05 & 5.65 \\
\hline Flota Grande & 48.49 & 214 & $116,980.00$ & $490,468.00$ & $71,200.45$ & $95.54 \%$ & $60.87 \%$ & 58.60 & 6.89 \\
\hline Flota Mediana & 32.82 & 1148 & $409,730.00$ & $1,160,889.00$ & $216,660.78$ & $100.99 \%$ & $52.88 \%$ & 42.16 & 5.36 \\
\hline Flota Pequeña & 30.97 & 450 & $116,980.00$ & $357,461.00$ & $67,399.33$ & $101.54 \%$ & $57.62 \%$ & 36.88 & 5.30 \\
\hline 日 Temporada 2017-II-Norte & 34.82 & 711 & $256,405.00$ & $991,243.00$ & $107,129.34$ & $42.54 \%$ & $41.78 \%$ & 47.63 & 9.25 \\
\hline Flota Grande & 45.59 & 73 & $40,980.00$ & $211,752.00$ & $18,968.53$ & $35.87 \%$ & $46.29 \%$ & 72.67 & 11.16 \\
\hline Flota Mediana & 32.34 & 487 & $176,110.00$ & $599,392.00$ & $72,087.09$ & $47.36 \%$ & $40.93 \%$ & 45.91 & 8.31 \\
\hline Flota Pequeña & 37.51 & 151 & $39,315.00$ & $180,099.00$ & $16,073.73$ & $34.40 \%$ & $40.88 \%$ & 37.21 & 11.20 \\
\hline 曰 Temporada 2016-II-Norte & $21,688.96$ & 2272 & $811,260.00$ & $3,071,178.00$ & $326,083.77$ & $98.68 \%$ & $40.19 \%$ & 47.09 & 9.42 \\
\hline Flota Grande & $4,210.22$ & 246 & $132,210.00$ & $668,592.00$ & $63,059.16$ & $88.85 \%$ & $47.70 \%$ & 76.10 & 10.60 \\
\hline Flota Mediana & $21,388.94$ & 1488 & $538,660.00$ & $1,849,431.00$ & $203,633.85$ & $102.84 \%$ & $37.80 \%$ & 44.82 & 9.08 \\
\hline Flota Pequeña & $30,510.80$ & 538 & $140,390.00$ & $553,155.00$ & $59,390.76$ & $96.65 \%$ & $42.30 \%$ & 36.47 & 9.31 \\
\hline
\end{tabular}

Figure 12. Analysis report by vessel size.

Source: own elaboration.

Next, we are going to show the dictionary of key words regarding the fishing process:

- Cycle time: It is the average time it takes for a vessel, waiting in port, unloading the catch and the time it takes to set sail again.

- Number of trips: The number of trips made by the vessels as a whole.

- Hold capacity: The storage capacity of the vessels as a whole, expressed by the number of trips.

- Fuel consumption Gl/h: It is the fuel consumption per hour of the vessels.

- Fuel consumption Gl/TN: Fuel consumption per tons fished.

\section{CONCLUSIONS}

An improvement in operational efficiency was increased through the digital transformation in the collection processes, since it reached an increase in the last 4 years with a normal margin of $80.9 \%$. In the year 2020 the objective was achieved and the margin of $407,813 \mathrm{TN}$ was exceeded. In addition, there is a bar system that shows the amount of catches obtained during the year, observing the development and progress of Peruvian productions. 
Harvesting efficiency was improved through the application of digital transformation in harvesting processes as there was moderate consumption with the bar platform evaluating the harvesting margin of fish for 4 to 5 years, achieving the objective as a point of improvement. within marine production.

A lower consumption of 1,845 million gallons could be obtained in reference to previous years due to the effectiveness of the platform that was able to evaluate the points in favor for production from the production analysis to the unloading times and waiting for delivery of the products. Sea products.

There was a total improvement in performance and reference based on the implementation of digital transformation in the collection processes with a margin of $70.37 \%$ in 2020 - I, $46.55 \%$ in 2020 - II, a higher rate than expected allowing invest in different resources that can help the production processes of the harvest based on different flexible techniques to be able to have fishing processes based: fuel, ship conditions, unloading time and sailing time, a lot of criteria must be considered in order to be able to have the highest effectiveness in the production method.

\section{REFERENCES}

Bradley, D., Merrifield, M., Miller, K. M., Lomonico, S., Wilson, J. R., \& Gleason, M. G. (2019). Opportunities to improve fisheries management through innovative technology and advanced data systems. Fish and Fisheries, 20(3), 564-583. http:// dx.doi.org/10.1111/faf.12361

Correa, J. I., \& López, M. (2007). Planeación estratégica de tecnologías de informáticas y sistemas de información. Editorial Universidad de Caldas.

Falcón, J.G.B., Rodriguez, G.R., \& Vargas, D.E. (2019). Real time facial expression recognition system based on deep learning. International Fournal of Recent Technology and Engineering (IFRTE), 8(2S11), p.4049. https://www.ijrte.org/wp-content/uploads/ papers/v8i2S11/B15910982S1119.pdf

FAO. (2018). El estado mundial de la pesca y la acuicultura. 
Hitpass. (2017). BPM: Business Process Management: Fundamentos y Conceptos de Implementación. BHH Ltda.-Santiago de Chile

Igarza, E. (2018). Efectos de la Aplicación del M-Learning en el Desempeño Académico de los Estudiantes del Curso de Matemática de la Facultad de Ingeniería de Sistemas e Informática. Universidad Nacional de San Martín-Tarapoto.

Levy, J., Pandey, B., Chowdhry, B., \& Rodriguez, C. (2020). Prologue: Recent trends in computer science and engineering (RTCSE). 3C Tecnología. Glosas De Innovación Aplicadas a La Pyme, 19-25. https://ojs.3ciencias.com/index.php/3ctecnologia/ article/view/991

Luna, F. (2016). Desarrollo web para dispositivos móriles: Herramientas para diseñar y programar WebApps. Creative Andina Corp

Mnatsakanyan, A. G., \& Kharin, A. G. (2021). Digitalization in the context of solving ecosystem problems in the fishing industry. IOP Conference Series. Earth and Environmental Science, 689(1). http://dx.doi.org/10.1088/1755-1315/689/1/012008

Otero, A. D. (2014). Modelo de aprendizaje móvil abierto para educación superior. Universidad Veracruzana. https://cdigital.uv.mx/handle/123456789/41450

Rodriguez, G., Lezama, P., Freddy, K., \& Chavez, D. (2020). Bayesian model to determine genealogical links of family descendants. Test Engineering and Management, 83, 17937-17946.

Ubalde, R., Rodriguez, C., Petrlik, I., Esenarro, D., Lezama, P., \& Sotomayor, J. (2020). Quality model for peruvian microenterprises of a software product factory. Test Engineering and Management, 83, 13434-13441. 
